\title{
Diet of tadpoles of five anuran species from northeast Brazil
}

\author{
Airan dos Santos Protázio, ${ }^{1 *}$ Arielson dos Santos Protázio, ${ }^{2}$ Vívian Gama, ${ }^{2}$ Samantha Vieira Silva ${ }^{3}$, \\ Carla Giovanna Cruz dos Santos, ${ }^{1}$ Joanna Karine Gomes de Oliveira ${ }^{2}$
}

${ }^{1}$ Departamento de Ensino, Instituto Federal de Educação, Ciência e Tecnologia da Bahia, Irecê, Bahia; ${ }^{2}$ Centro de Ciências Agrárias, Ambientais e Biológicas, Universidade Federal do Recôncavo da Bahia, Cruz das Almas, Bahia; ${ }^{3}$ Departamento de Biologia, Universidade Federal de Sergipe, São Cristovão, Sergipe, Brazil

\begin{abstract}
In this study, the diet of tadpoles of five anuran species was described. The species were collected from either lotic or lentic environments in Caatinga and the Atlantic Forest biome of northeast Brazil. The diet of these tadpoles consisted of algae, protozoa, plants, fungi and animals. Diatoms were the most important items within the diet of Leptodactylus natalensis. Trachelomonas, diatoms, Phacus and Scenedesmus were the most important items comprising the diet of Leptodactylus cf. macrosternum. Trachelomonas, Oscillatoria and Scenedesmus were the most important items comprising the diet of Pithecopus nordestinus. Diatoms and Scenodesmus were the most important items of the diet for Rhinella jimi. For Scinax x-signatus, diatoms (Atlantic Forest population), Oscillatoria, undetermined filament and pollen (Caatinga population) were the most important items consumed. Scinax $x$-signatus and L. natalensis from Atlantic Forest, and L. cf. macrosternum and P. nordestinus from Caatinga had diets that were the most similar. The diversity of items found in the diets of species considered may be attributed to mechanisms used by tadpoles to obtain food, which favour the acquisition of suspended materials that are highly available in the environment. We discuss the possible effects of the relationship between algae and tadpoles and the importance of recording larvae diets to better understand the dynamics of the aquatic environment and the trophic ecology of tadpoles.
\end{abstract}

\section{INTRODUCTION}

The larvae of frogs can be found in a variety of environments and are important components of the aquatic and terrestrial food webs of many systems. For example, tadpoles are important prey of both vertebrates and invertebrates. Furthermore, tadpole grazing can structure communities through the regulation of primary production in the environment (Seale, 1980; Loman, 2001). However, researchers have a limited understanding of the trophic ecology of anuran larvae in comparison with adult forms. This is partly due to the lack of studies regarding the food habits of tadpoles, which has hindered our ability to fully understand the natural history of the

Corresponding author: airanprotazio@yahoo.com.br

Key words: Food; larvae; permanent stream; temporary pond; lagoon.

Edited by: Diego Fontaneto, CNR-IRSA, Verbania, Italy.

Received: 21 April 2019

Accepted: 28 February 2020

This work is licensed under a Creative Commons Attribution NonCommercial 4.0 License (CC BY-NC 4.0).

${ }^{\circ}$ Copyright: the Author(s), 2020

Licensee PAGEPress, Italy

J. Limnol., 2020; 79(2): 180-186

DOI: 10.4081/jlimnol.2020.1912 species and its functional role in the environment throughout the tadpole phase (Huckembeck et al., 2016).

Overall, studies on the diet of tadpoles have focused on their eating habits (Arias et al., 2002; Candioti, 2005; Sousa Filho et al., 2007), the influence of food on individual development (Steinwascher and Travis, 1983; Álvarez and Nicieza, 2002; Iwai and Kagaya, 2005), the relationship between ingested items and the degree of conservation of the environment (Bionda et al., 2012; Bionda et al., 2013), the relationship between sympatric species (Rossa-Feres et al., 2004; Pollo et al., 2015; Santos et al., 2016) and the effects of tadpole grazing on algal community structure (Seale, 1980; Loman, 2001; Ranvestel et al., 2004). Nevertheless, few of the many known species of anurans have had their larval diets described.

In this study, we describe the diets of tadpoles of five anuran species from northeast Brazil. The frog species Leptodactylus natalensis (Lutz, 1930) occurs in coastal regions from Northeast Brazil to the state of Rio de Janeiro (Sá et al., 2014). This frog presents parental care and spawns in cavities on the banks of bodies of water (Santos and Amorim, 2005, 2006). The frog Leptodactylus cf. macrosternum (Miranda-Ribeiro, 1926) is widely distributed across South America, ranging from the Amazon to the Caatinga and the Atlantic Forest of eastern Brazil (Frost, 2020). Individuals of this species can be found partially submerged or near bodies of water (Protázio et al., 2015). The tree frog Pithecopus nordestinus (Caramaschi, 2006), which is found both in the Caatinga biome and in the Caatinga-Cerrado and Caatinga-Atlantic Forest ecotones (Caramaschi, 2006), 
reproduces in lentic and temporary bodies of water (Caldas et al., 2016). The toad Rhinella jimi (Stevaux, 2002) is distributed throughout northeast Brazil. This species is associated with secondary forests and open areas, and uses permanent and temporary bodies of water for reproduction (Andrade and Carnaval, 2004). Finally, Scinax $x$-signatus (Spix, 1824) is a tree frog that is widely distributed across South America, inhabiting open areas and forest edges. It breeds in standing water (permanent and temporary) (Rodrigues et al., 2010).

The tadpoles were found in a permanent stream $(L$. natalensis) and temporary pond (S. x-signatus) in the Atlantic Forest, and in a lagoon $(R$. jimi) and a temporary pond (L. cf. macrosternum, $P$. nordestinus and $S$. $x$ signatus) in Caatinga.

\section{METHODS}

The tadpoles were collected from four different locations in northeast Brazil (Fig. 1). Leptodactylus natalensis were collected in November 2010 from a stream approximately $3 \mathrm{~m}$ wide and $0.70 \mathrm{~m}$ deep, which was located within a nature reserve known as the Mata do Açude Cafundó in the Cruz do Espírito Santo municipality, Paraíba State $\left(07^{\circ} 10^{\prime} 48^{\prime \prime} \mathrm{S}, 35^{\circ} 05^{\prime} 39^{\prime} \mathrm{W}\right)$. This area, comprised of semi-deciduous seasonal forest, is approximately 730 ha in size and has a tropical climate. A monoculture of sugar cane surrounds the area (Rodrigues et al., 2013). Leptodactylus cf. macrosternum, $P$. nordestinus, and $S$. $x$-signatus (Caatinga population) were collected in January and June 2016 from a temporary pond located in the road banks (BA148) in the Irecê municipality, Bahia State (11 $\left.{ }^{\circ} 19^{\prime} 36^{\prime \prime S}, 41^{\circ} 51^{\prime} 57^{\prime \prime} \mathrm{W}\right)$. Irecê lies within a Caatinga biome, with a semi-arid climate and intense temperatures, and commonly exhibits episodic droughts. The region is predominantly comprised of sparse shrubs, uncovered soil, and exposed rocky outcrops.

Tadpoles from a second population of $S$. x-signatus (Atlantic Forest population) were collected in August 2016 from a temporary pond formed next to a lake known as Lagoa da Cascalheira in the Cruz das Almas municipality,

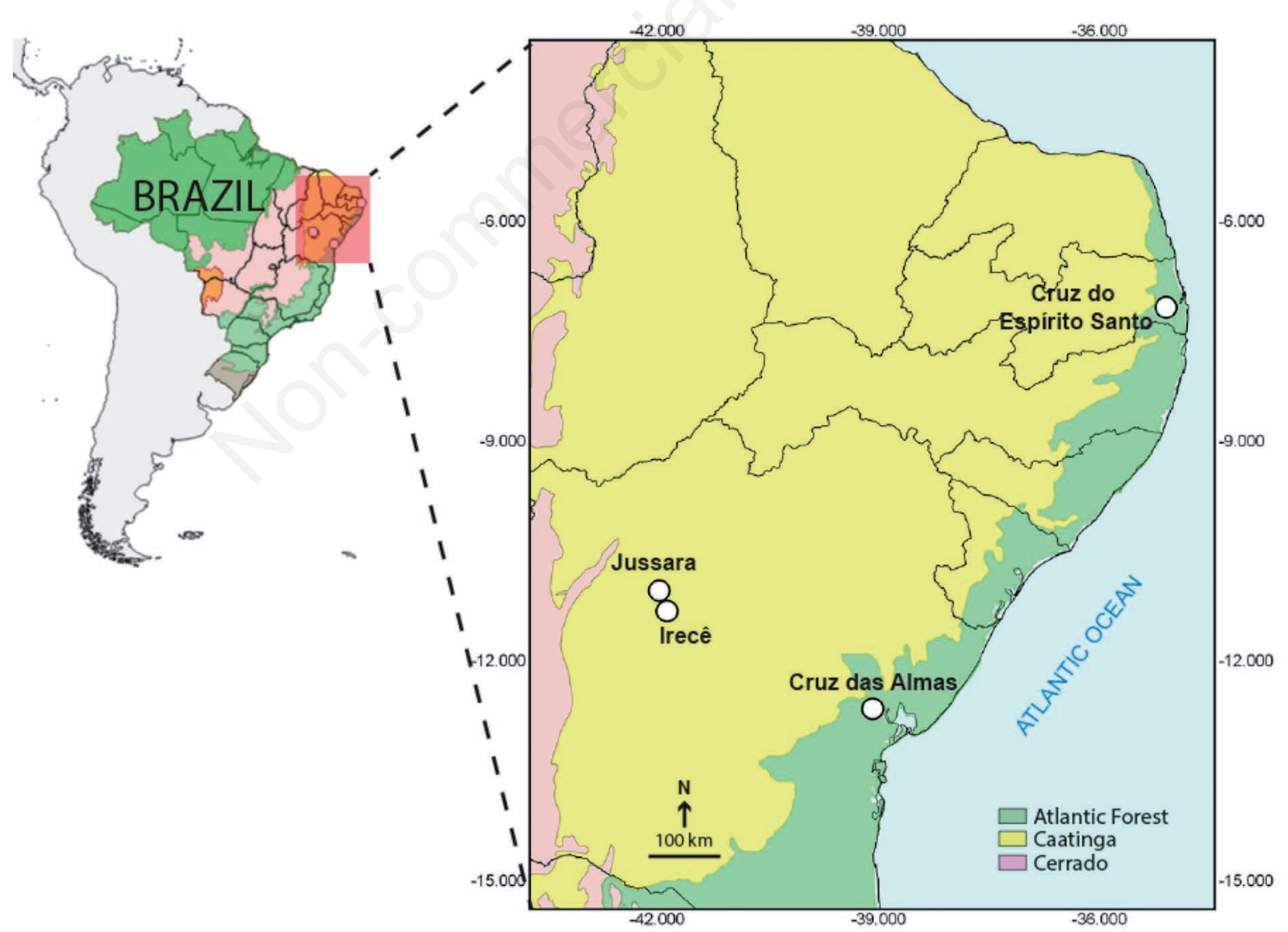

Fig. 1. Geographical location of the four municipalities where were obtained tadpoles of the species examined. Cruz das Almas: Scinax x-signatus; Cruz do Espírito Santo: Leptodactylus natalensis; Irecê: Leptodactylus cf. macrosternum, Pithecopus nordestinus and Scinax $x$-signatus; Jussara: Rhinella jimi. 
Bahia State (12³9'32'S, 3904'37'W). Cruz das Almas lies within the Atlantic Forest biome and has a tropical rainy climate, with a mean annual precipitation of $1143 \mathrm{~mm}$. The semi-deciduous seasonal forest hosts its original vegetation, yet intense use and deforestation of the area has resulted in the forest being reduced to small fragments. Finally, R. jimi was collected in January 2018 from a lagoon in the Jussara

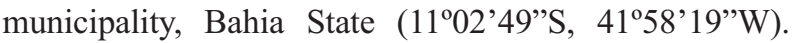
Jussara is located within the Caatinga biome and has a semiarid climate. The lagoon is located in an urban environment where the original vegetation was modified during the implementation of residential construction projects.

Collected individuals were killed using 70\% ethanol and preserved in $10 \%$ formalin to suspend the digestive process and preserve intestinal content. The diets of the following sets of tadpoles were analysed: five $L$. natalensis (phases 29 to 38), L. cf. macrosternum (phases 36 to 38), and $P$. nordestinus (phases 31 to 37) tadpoles; fifteen R. jimi (phases 31 to 35) tadpoles; and nine S. $x$ signatus tadpoles from the Atlantic Forest (phases 34 to 40) and Caatinga (phase 26). The phases of development were evaluated in accordance with Gosner (1960) and tadpoles were identified based on comparisons with previously metamorphosed individuals and existing descriptions found in the literature.

To analyse the diets of tadpoles, intestines of individuals were removed by making an incision that extended from the cloaca to the oral disc of each tadpole using a stereomicroscope. The intestines were subsequently opened in a Petri plate and their contents were removed by making longitudinal cuts. Finally, intestinal contents were mixed with $4 \%$ formalin and stored in microtubes. Two drops of each mixture, corresponding to a volume of $0.05 \mathrm{~mL}$, was placed on a slide $(74 \times 24 \mathrm{~mm}$ or $76.2 \times 25.4 \mathrm{~mm})$, and a glass coverslip (50 × $20 \mathrm{~mm}$ or $22 \times 22 \mathrm{~mm})$ was added. The samples were examined under a light microscope (Biofocus BIO-1600 and Olympus CX21) at 40-, 60- and 100 -fold magnification. The procedure was repeated once and the results were combined.

The items observed in the intestines of tadpoles were identified to the lowest possible taxonomic level using a specialised bibliography and quantified based on numeric frequency $(\% \mathrm{NF})$, frequency of occurrence $(\% \mathrm{FO})$, and the importance index (I). The importance index was obtained by adding the $\% \mathrm{NF}$ and $\% \mathrm{FO}$ and dividing by two. All collected tadpoles were deposited in the Herpetological Collection of the Universidade Federal do Recôncavo da Bahia.

A hierarchical clustering analysis was performed to assess the degree of similarity between the content of the digestive tracts of different species. For this analysis, the unweighted pair-group averages (UPGMA) algorithm and the Euclidian Distance Index with 1000 permutations in
Bootstrap were used. The cluster analysis was performed using Past 3.16 (Hammer et al., 2017).

\section{RESULTS}

A wide range of items were found in the digestive tracts of the collected tadpoles. Algae, protozoa, and plant fragments were identified as being constituents of the diet of $L$. natalensis. A total of 111 items distributed into eight categories were counted in diet of the species (Tab. 1). Based on the importance index, diatoms (Bacillariophyceae) was the most relevant category, followed by undetermined items and Trinema. In diet of $L$. cf. macrosternum, Euglenophyceae, diatoms, Chlorophyceae algae and protozoa were recorded. A total of 994 items distributed into twenty-two prey categories were counted (Tab. 2). Trachelomonas, Bacillariophyceae, Phacus and Scenedesmus were the most important categories. The diet of $P$. nordestinus was composed of algae, protozoa, plants and animals. A total of 1748 items distributed in twenty-two prey categories were counted for this species (Tab. 3). Trachelomonas was the most important category, followed by Oscillatoria, Scenedesmus, and animal eggs. The diet of $R$. jimi was mainly comprised of algae, although fungi, protozoa, animal fragments, and plants were also observed (Tab. 4). The R. jimi diet comprised a total of 6984 items distributed into twenty categories. Bacillariophyceae, Scenodesmus, Cyanophycea undetermined, Trachelomonas, and Monactinus were the most important categories. Finally, the diet of S. x-signatus from the temporary pond of the Atlantic Forest was mainly comprised of algae (Tab. 5). A total of 1748 items divided into thirteen categories were counted. Bacillariophyceae was the most important category, followed by undetermined items and Trachelomonas. The diet of the S. x-signatus from the temporary pond in Caatinga was mainly comprised of Cyanophycea algae. A total of the 222 items distributed into nineteen categories were counted. Oscillatoria, undetermined filament, and pollen (spermatophyte) were the most important categories.

Topology constructed from the items found in the intestinal content of tadpoles has shown that the diets of some species were similar, especially with respect to those species that lived within the same biome (Fig. 2). Scinax $x$-signatus and L. natalensis from Atlantic Forest, as well as $L$. cf. macrosternum and P. nordestinus from Caatinga were shown to have dietary similarities that were moderately supported by Bootstrap analysis $(75 \%$ and $73 \%$, respectively). Scinax $x$-signatus and R. jimi from Caatinga were exceptions. Although both populations of S. x-signatus (Atlantic Forest and Caatinga) were determined to be similar, their grouping was only weakly supported (35\% via Bootstrap analysis). Additionally, the Caatinga population of $S$. $x$-signatus presented the lowest 
level similarity with the other species that lived within the same biome, while $R$. jimi had the lowest level of similarity with all species and formed an isolated group.

Tab. 1. Diet of the Leptodactylus natalensis $(n=5)$ of the permanent stream in the Cruz do Espírito Santo municipality, Paraíba State, Northeastern Brazil.

\begin{tabular}{|c|c|c|c|}
\hline Food items & $\%$ NF & $\% \mathrm{FO}$ & I \\
\hline $\begin{array}{l}\text { Bacillariophyceae } \\
\text { Pennales }\end{array}$ & 43.2 & 100 & 93.2 \\
\hline $\begin{array}{l}\text { Cyanophyceae } \\
\text { Haplotaenium } \\
\text { Plancktonlyngbya }\end{array}$ & $\begin{array}{l}0.9 \\
3.6\end{array}$ & $\begin{array}{l}20 \\
40\end{array}$ & $\begin{array}{l}10.9 \\
23.6\end{array}$ \\
\hline $\begin{array}{l}\text { Protozoa } \\
\text { Arcella } \\
\text { Trinema }\end{array}$ & $\begin{array}{l}0.9 \\
8.1\end{array}$ & $\begin{array}{l}20 \\
40\end{array}$ & $\begin{array}{l}10.9 \\
28.1\end{array}$ \\
\hline $\begin{array}{l}\text { Spermatophyta } \\
\text { Fragment }\end{array}$ & 3.6 & 40 & 23.6 \\
\hline $\begin{array}{l}\text { UND item } 1 \\
\text { UND item } 2\end{array}$ & $\begin{array}{c}35.1 \\
4.5\end{array}$ & $\begin{array}{l}60 \\
20\end{array}$ & $\begin{array}{l}65.1 \\
14.5\end{array}$ \\
\hline
\end{tabular}

Tab. 2. Diet of the Leptodactylus cf. macrosternum ( $\mathrm{n}=5$ ) of temporary pond in the Irecê municipality, Bahia State, Northeastern Brazil.

\begin{tabular}{|c|c|c|c|}
\hline Food items & $\% \mathrm{FN}$ & $\% \mathrm{FO}$ & I \\
\hline \multicolumn{4}{|l|}{ Bacillariophyceae } \\
\hline Pennales & 15.7 & 100 & 65.8 \\
\hline \multicolumn{4}{|l|}{ Cyanophyceae } \\
\hline Anabaena & 0.1 & 20 & 10.1 \\
\hline Leibleinia & 0.1 & 20 & 10.1 \\
\hline Oscillatoria & 1.1 & 80 & 41.1 \\
\hline Spirulina & 0.4 & 20 & 10.4 \\
\hline UND Filament & 2.9 & 100 & 52.9 \\
\hline \multicolumn{4}{|l|}{ Chlorophyceae } \\
\hline Scenedesmus & 7.6 & 100 & 57.6 \\
\hline \multicolumn{4}{|l|}{ Euglenophyceae } \\
\hline Euglena & 5.8 & 100 & 55.8 \\
\hline Phacus & 12.3 & 100 & 62.3 \\
\hline Trachelomonas & 38.8 & 100 & 88.8 \\
\hline UND 1 & 0.3 & 20 & 10.3 \\
\hline UND 2 & 2.5 & 100 & 52.5 \\
\hline UND 3 & 0.8 & 40 & 20.8 \\
\hline \multicolumn{4}{|l|}{ Protozoa } \\
\hline Arcella & 0.1 & 20 & 10.1 \\
\hline Difflugia & 0.1 & 20 & 10.1 \\
\hline Trinema & 1.4 & 20 & 11.4 \\
\hline UND 1 & 6.4 & 60 & 36.4 \\
\hline UND 2 & 1.1 & 20 & 11.1 \\
\hline \multicolumn{4}{|l|}{ Spermatophyta } \\
\hline Pollen & 1.1 & 60 & 31.1 \\
\hline Animal (egg) & 0.4 & 60 & 30.4 \\
\hline UND item 1 & 0.3 & 20 & 10.3 \\
\hline UND item 2 & 0.3 & 20 & 10.3 \\
\hline
\end{tabular}

Tab. 3. Diet of the Pithecopus nordestinus $(\mathrm{n}=5)$ of temporary pond in the Irecê municipality, Bahia State, Northeastern Brazil.

\begin{tabular}{|c|c|c|c|}
\hline Food items & $\% \mathrm{FN}$ & $\% \mathrm{FO}$ & I \\
\hline $\begin{array}{l}\text { Bacillariophyceae } \\
\text { Pennales }\end{array}$ & 4.1 & 100 & 54.1 \\
\hline $\begin{array}{l}\text { Cyanophyceae } \\
\text { Glaucospira } \\
\text { Oscillatoria } \\
\text { Spirogyra } \\
\text { Spirulina } \\
\text { UND Filament }\end{array}$ & $\begin{array}{c}1.1 \\
15.9 \\
1.0 \\
0.7 \\
0.5\end{array}$ & $\begin{array}{c}80 \\
100 \\
20 \\
60 \\
60\end{array}$ & $\begin{array}{l}41,1 \\
65.9 \\
11.0 \\
30.7 \\
30.5\end{array}$ \\
\hline $\begin{array}{l}\text { Chlorophyceae } \\
\text { Pediastrum } \\
\text { Scenedesmus }\end{array}$ & $\begin{array}{c}0.1 \\
12.2\end{array}$ & $\begin{array}{c}20 \\
100\end{array}$ & $\begin{array}{l}10.1 \\
62.2\end{array}$ \\
\hline $\begin{array}{l}\text { Euglenophyceae } \\
\text { Euglena } \\
\text { Phacus } \\
\text { Trachelomonas }\end{array}$ & $\begin{array}{c}0.8 \\
1.8 \\
26.9\end{array}$ & $\begin{array}{c}60 \\
80 \\
100\end{array}$ & $\begin{array}{l}30.8 \\
41.8 \\
76.9\end{array}$ \\
\hline $\begin{array}{l}\text { Zygnemaphyceae } \\
\text { Cosmarium } \\
\text { Closterium } \\
\text { Zygogonium } \\
\text { UND 1 } \\
\text { UND } 2\end{array}$ & $\begin{array}{c}1.2 \\
14.0 \\
0.1 \\
0.2 \\
1.0\end{array}$ & $\begin{array}{l}80 \\
20 \\
40 \\
20 \\
80\end{array}$ & $\begin{array}{l}41.2 \\
24.0 \\
20.1 \\
10.2 \\
41.0\end{array}$ \\
\hline $\begin{array}{l}\text { Protozoa } \\
\text { Aconthocystis } \\
\text { Opalina }\end{array}$ & $\begin{array}{l}3.5 \\
6.2\end{array}$ & $\begin{array}{l}40 \\
60\end{array}$ & $\begin{array}{l}23.5 \\
36.2\end{array}$ \\
\hline $\begin{array}{l}\text { Spermatophyta } \\
\text { Pollen } \\
\text { Fragments }\end{array}$ & $\begin{array}{l}0.2 \\
0.1\end{array}$ & $\begin{array}{l}40 \\
40\end{array}$ & $\begin{array}{l}20.2 \\
21.1\end{array}$ \\
\hline Animal (egg) & 7.9 & 100 & 57.9 \\
\hline UND item & 0.4 & 20 & 10.4 \\
\hline
\end{tabular}

Tab. 4. Diet of Rhinella jimi $(\mathrm{n}=15)$ of a lagoon in the Jussara municipality, Bahia State, Northeastern Brazil.

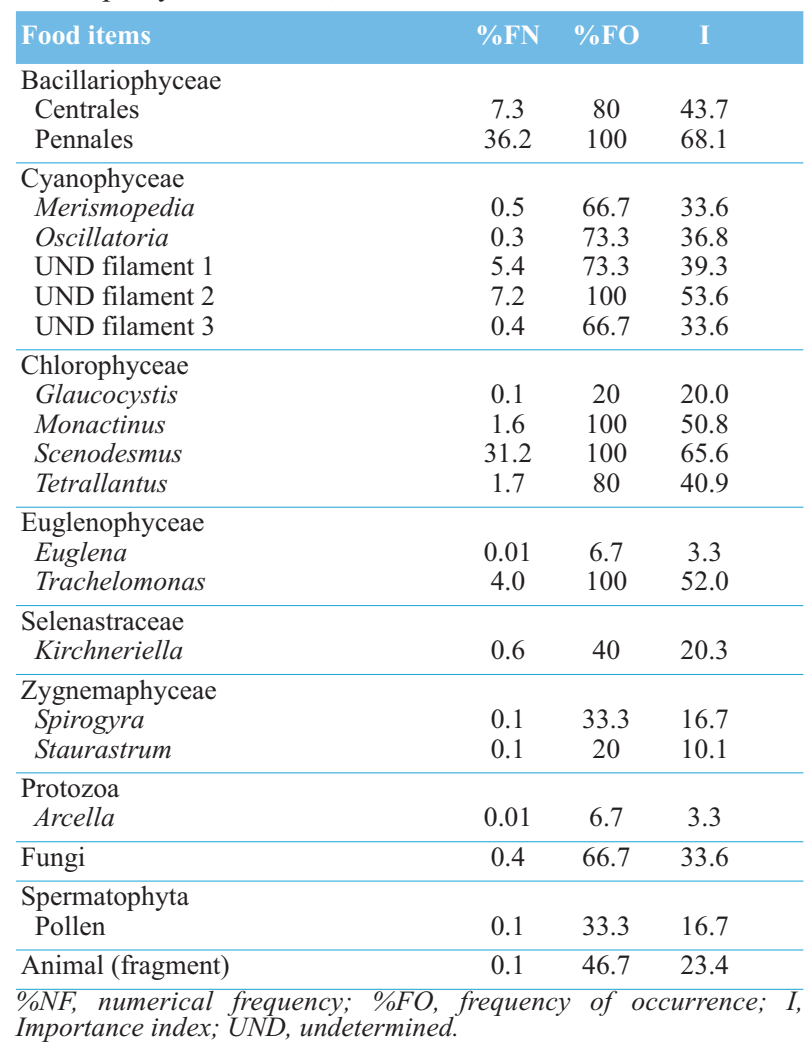


Tab. 5. Diet of Scinax $x$-signatus of the temporary pond in the Atlantic Forest $(n=4)$ (Cruz das Almas municipality) and temporary pond in Caatinga $(\mathrm{n}=5)$ (Irecê municipality), Bahia State, Northeastern Brazil.

\begin{tabular}{|c|c|c|c|c|c|c|}
\hline \multirow[t]{2}{*}{ Food items } & \multicolumn{3}{|c|}{$\begin{array}{c}\text { Atlantic Forest } \\
\text { population }\end{array}$} & \multicolumn{3}{|c|}{$\begin{array}{l}\text { Caatinga } \\
\text { population }\end{array}$} \\
\hline & $\% \mathrm{NF}$ & $\% \mathrm{FO}$ & I & $\% \mathrm{NF}$ & $\%$ FO & I \\
\hline \multicolumn{7}{|l|}{ Bacillariophyceae } \\
\hline Centrales & 0.1 & 25 & 12.5 & - & - & - \\
\hline Pennales & 86.4 & 100 & 93.2 & 1.3 & 60 & 31.3 \\
\hline \multicolumn{7}{|l|}{ Cyanophyceae } \\
\hline Anabaena & - & - & - & 0.9 & 20 & 10.8 \\
\hline Leibleinia & - & - & - & 4.2 & 20 & 14.2 \\
\hline Oscillatoria & - & - & - & 18.9 & 100 & 69.0 \\
\hline Plancktonlyngbya & - & - & - & 0.4 & 20 & 10.4 \\
\hline Rhabdoderma & - & - & - & 7.2 & 60 & 37.2 \\
\hline Scytonema & - & - & - & 0.4 & 20 & 10.4 \\
\hline Spirulina & - & - & - & 1.3 & 20 & 11.3 \\
\hline UND filament 1 & 0.3 & 25 & 12.7 & - & - & - \\
\hline UND filament 2 & - & - & - & 16.5 & 100 & 66.5 \\
\hline \multicolumn{7}{|l|}{ Chlorophyceae } \\
\hline Closterium & 0.1 & 50 & 25.1 & - & - & - \\
\hline Scenedesmus & - & - & - & 2.1 & 80 & 42.1 \\
\hline UND filament & 0.5 & 100 & 50.3 & - & - & - \\
\hline \multicolumn{7}{|l|}{ Euglenophyceae } \\
\hline Euglena & 0.2 & 50 & 25.1 & 0.4 & 20 & 10.4 \\
\hline Phacus & 0.3 & 50 & 25.2 & - & - & - \\
\hline Trachelomonas & 2.5 & 100 & 51.3 & 10.1 & 60 & 40.1 \\
\hline \multicolumn{7}{|l|}{ Zygnemaphyceae } \\
\hline Cosmarium & - & - & - & 0.8 & 20 & 10.8 \\
\hline Closterium & - & - & - & 2.1 & 20 & 12.1 \\
\hline Sirogonium & - & - & - & 1.3 & 40 & 21.3 \\
\hline Spirotaenia & - & - & - & 0.4 & 20 & 10.4 \\
\hline \multicolumn{7}{|l|}{ Xanthophyceae } \\
\hline Lutherella & - & - & - & 0.8 & 20 & 10.8 \\
\hline \multicolumn{7}{|l|}{ Protozoa } \\
\hline Arcella & 0.4 & 50 & 25.2 & - & - & - \\
\hline \multicolumn{7}{|l|}{ Spermatophyta } \\
\hline Fragment & 0.3 & 50 & 25.2 & - & - & - \\
\hline Pollen & 1.5 & 50 & 25.7 & 9.3 & 100 & 59.3 \\
\hline Fungi & - & - & - & 0.8 & 40 & 20.8 \\
\hline Animal (egg) & 0.1 & 25 & 12.5 & - & - & - \\
\hline UND item & 7.3 & 100 & 53.6 & - & - & - \\
\hline
\end{tabular}

EUCLIDEAN DISTANCE

$200180160140120100 \quad 80 \quad 60 \quad 40 \quad 20$

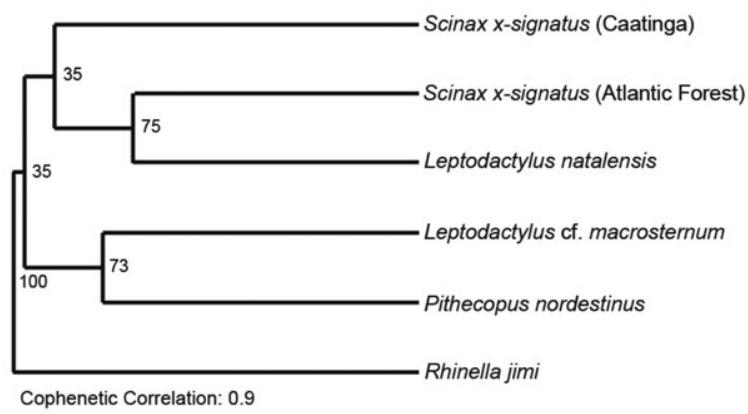

Fig. 2. Dendrogram built using the UPGMA method with the dietary information of tadpoles of five species. Node numbers indicate sustained values from Bootstrap.

\section{DISCUSSION}

Our results have shown that the larvae of the five species preferentially consumed algae, but also ate protozoa, plant, animal and fungi in lesser proportions. This feeding behaviour is common among tadpoles, and allows us to classify them as omnivores or detritivores (Hoff et al., 1999). Algae were of great importance in the diet of the tadpoles, and was the most frequently identified group in the intestinal content of tadpoles examined in this study. Consumption of a large number of algal species places tadpoles in an important position within the food web in which they are able to drastically influence the energy flow through the environment. For this reason, some studies have proposed that the relationship between tadpoles and algae be studied. Ranvestel et al. (2004) investigated the effect of tadpoles on the structure of the lotic environmental community (algae and aquatic insects) and concluded that tadpoles affected the abundance and diversity of the basal source and other primary consumers. The authors observed a $50 \%$ reduction in algal abundance in the presence of tadpoles. Seale (1980) and Loman (2001), who examined the feeding behaviour of tadpoles in lentic environments, presented similar results. The great abundance and diversity of algal species recorded in the diet of tadpoles from northeast Brazil confirms these findings and underscores the importance of investigating the role of tadpoles within the aquatic system.

Other investigations regarding the relationship between tadpole and algal species have focused on the physiological effects of algae on tadpole development. Pryor (2003) and Akers et al. (2008) noted that algae are not well digested by tadpoles. Kupferberg et al. (1994), analysed the influence of algae on the development of tadpoles, and found that consumption of both algal species and diatoms is highly efficient. The authors noted high levels of proteins and fats available to tadpoles that had consumed diatoms in comparison with those that had consumed exclusively algal species. Diatoms (Bacillariophyceae) were one of the most important items in the tadpole diet of the five species examined in this study. They have also been cited as the most frequently consumed item in the diets of other tadpoles of lotic (Santos et al., 2016) and lentic (Rossa-Feres et al., 2004; Echeverría et al., 2007; Bionda et al., 2012; Huckembeck et al., 2016) environments, indicating that high levels of diatoms in intestinal contents of tadpoles can be considered a general phenomenon. This information is relevant to studies examining the food preferences of anurans and environmental monitoring, including studies that evaluate the presence or absence of certain diatomaceous groups, which can be considered indicators of environmental quality (Cejudo-Figueiras et al., 2010; Antón-Garrido et al., 2013). 
Other items found in the diet of the tadpoles examined were plant fragments, protozoa, fungi and animal parts. Few studies have discussed the relevance of these items. An exception is a study by Santos et al. (2016), who observed the presence of these items in the diet of Bokermanohyla capra Napoli \& Pimenta, 2009, Aplastodiscus cavicola (Cruz \& Peixoto, 1985) and Aplastodiscus sibilatus (Cruz, Pimenta \& Silvano, 2003) tadpoles living in sympatry in Atlantic Forest tropical streams. In addition, Dutra and Callisto (2005) investigated the importance of invertebrates in the diets of tadpoles, Nathan and James (1972) studied the relevance of protozoa in the diet of frog larvae and RossaFeres et al. (2004) characterised the mycophagous habit of tadpoles of Leptodactylus fuscus (Schneider, 1799), a congeneric species of $L$. natalensis. However, there was low degree of representation of these items in the diet of the five species examined in this study, despite the overall importance of the items. Fungi, for example, was only recorded as being a component of the diets $S$. x-signatus (Caatinga population) and $R$. jimi species.

A comparison between the diet of the populations surveyed here with other populations was not possible. Previous studies investigating the diets of Leptodactylus natalensis, Leptodactylus cf. macrostermum, Pithecopus nordestinus, Rhinella jimi and Scinax x-signatus tadpoles are not available. However, when we compared the diets of $S$. $x$-signatus populations from the Atlantic Forest and Caatinga, we observed that there were differences between ingested items. The Caatinga population consumed a higher variety of items when compared with the Atlantic Forest population. In addition, when the diets of the five species identified were compared, we observed that species from the Atlantic Forest and Caatinga biomes form conspicuous groups. The population of $S$. $x$-signatus from Caatinga, which had a high degree of similarity with the populations from the Atlantic Forest, was the exception. The feeding habits of tadpoles have already been determined to be a result of their mode of food acquisition and morphology (Wells, 2007). Most tadpoles feed by pumping water and suspended particles into their mouths. Therefore, their food is based on a nonselective filter, which leads to the acquisition of items that are abundant in the environment (Altig and Johnston, 1989; Alford, 1999; Wells, 2007), which is in accordance with our findings.

\section{CONCLUSIONS}

Tadpoles of five anuran species displayed omnivorous or detritivore-like feeding characteristics, and consumed algae, protozoa, plants, fungi and animals. The high degree of representation of algae in diet of species examined underscores its importance in the trophic niche of the tadpoles. In addition, these results demonstrate the need for studies investigating the trophic niche of tadpoles and their functional role in the environment. This will provide researchers with a better understanding of the mechanisms that regulate the acquisition of resources by tadpoles, as well as their development, behaviour, phylogenetic relationships and the overall dynamics of the aquatic environment.

\section{ACKNOWLEDGMENTS}

We thank Instituto Federal da Bahia, Campus Irecê, for scholarships from Programa de Incentivo à Aprendizagem awerded to SVS and CGCS and the Instituto Chico Mendes de Conservação da Biodiversidade (ICMBio) for issued collecting permits (no. 46558-1, no. 46558-2 and no. 52867-1). We also thank to two anonymous referees for valuable comments on our manuscript.

\section{REFERENCES}

Akers EC, Taylor CM, Altig R, 2008. Effects of clay-associated organic material on the growth of Hyla chrysoscelis tadpoles. J. Herpetol. 42:408-410.

Alford RA, 1999. Resource use, competition, and predation, $\mathrm{p}$. 240-278. In: R.W. McDiarmid and R. Altig (eds.), Tadpole: the biology of anuran larvae. University of Chicago Press, Chicago.

Altig R, Johnston G, 1989. Guilds of anuran larvae: relationships among developmental modes, morphologies, and habitats. Herpetol. Monogr. 3:81-109.

Álvarez D, Nicieza AG, 2002. Effects of temperature and food quality on anuran larval growth and metamorphosis. Funct. Ecol. 16 640-648.

Andrade G, Carnaval AC, 2004. Rhinella jimi. The IUCN Red List of Threatened Species 2004. Available from: dx.doi.org/ 10.2305/IUCN.UK.2004.RLTS.T54674A11184744.en.

Antón-Garrido B, Romo S, Villena MJ, 2013. Diatom species composition and indices for determining the ecological status of coastal Mediterranean Spanish lakes. An. Jardin Bot. Madrid 70:122-135.

Arias MM, Peltzer PM, Lajmanovich RC, 2002. Diet of the giant tadpole Pseudis paradoxa platensis (Anura, Pseudidae) from Argentina. Phyllomedusa 1:97-100.

Bionda C, Gari N, Luque E, Salas N, Lajmanovich RC, Martino A, 2012. [Ecología trófica en larvas de Rhinella arenarum (Anura: Bufonidae) en agroecosistemas y sus posibles implicaciones para la conservación].[Article in Spanish]. Rev. Biol. Trop. 60:771-779.

Bionda C, Luque E, Gari N, Salas NE, Lajmanovich RC, Adolfo L, 2013. Diet of tadpoles of Physalaemus biligonigerus (Leiuperidae) from agricultural ponds in the central region of Argentina. Acta Herpetol. 8:141-146.

Caldas FLS, Silva BD, Santos RA, Carvalho CB, Santana DO, Gomes FFA, Faria RG, 2016. Autoecology of Phyllomedusa nordestina (Anura: Hylidae) in areas of the Caatinga and 
Atlantic Forest in the State of Sergipe, Brazil. North-Wester. J. Zool. 12:271-285.

Candioti MFV, 2005. Morphology and feeding in tadpoles of Ceratophrys cranwelli (Anura: Leptodactylidae). Acta Zool. 86: 1-11.

Caramaschi U, 2006. [Redefinição do grupo de Phyllomedusa hypochondrialis, com redescrição de $P$. megacephala (Miranda-Ribeiro, 1926), revalidação de P. azurea Cope, 1862 e descrição de uma nova espécie (Amphibia, Anura, Hylidae)].[Article in Portuguese]. Arq. Mus. Nac. 64:159179.

Cejudo-Figueiras C, Álvarez-Blanco I, Bécares E, Blanco S, 2010. Epiphytic diatoms and water quality in shallow lakes: the neutral substrate hypothesis revisited. Mar. Freshwater Res. 61:1457-1467.

Dutra SL, Callisto M, 2005. Macroinvertebrates as tadpole food: importance and body size relationships. Rev. Bras. Zool. 22:923-927.

Echeverría DD, Volpedo AV, Mascitti VI, 2007. Diet of tadpoles from a pond in Iguazu National Park, Argentina. Gayana 71:8-14.

Frost DR, 2020. Amphibian Species of the World: an Online Reference. Version 6.0. Available from: research.amnh.org/ herpetology

Gosner KL, 1960. A simplified table for staging anuran embryos larvae with notes on identification. Herpetologica 16:183-190.

Hammer Ø, Harper DAT, Ryan PD, 2017. PAST: Paleontological statistics software package for education and data analysis, version 3.16. Available from: http://folk.uio.no/ohammer/ past/.

Hoff K, Blaustein AR, McDiarmid RW, Altig R, 1999. Behavior: interactions and their consequences, p. 215-239. In: R.W. McDiarmid and R. Altig (eds.), Tadpole: the biology of anuran larvae. University of Chicago Press, Chicago.

Huckembeck S, Alves LT, Loebmann D, Garcia AM, 2016. What largest tadpoles feed on? A detailed analysis of the diet composition of Pseudis minuta tadpoles (Hylidae: Dendropsophini). An. Acad. Bras. Cien. 8:1397-1400.

Iwai N, Kagaya T, 2005. Growth of japanese toad (Bufo japonicus formosus) tadpoles fed different food items. Curr. Herpetol. 24:85-89.

Kupferberg SJ, Marks JC, Power ME, 1994. Effects of variation in natural algal and detrital diets on larval anuran (Hyla regilla) life- history traits. Copeia 1994: 446-457.

Loman J, 2001. Effects of tadpoles grazing on periphytic algae in ponds. Wetl. Ecol. Manag. 9:135-139.

Nathan JM, James VG, 1972. The role of protozoan in the nutrition of tadpoles. Copeia 1972:669-679.

Pollo FE, Martina LC, Bionda CL, Salas NE, Martino AL, 2015. Trophic ecology of syntopic anuran larvae, Rhinella arenarum (Anura: Bufonidae) and Hypsiboas cordabae (Anura: Hylidae): its relation to the structure of periphyton. Ann. Limnol. 51:211-217.
Protázio AS, Albuquerque RL, Falkenberg LM, Mesquita DO, 2015. Niche differentiation of an anuran assemblage in temporary ponds in the Brazilian semiarid Caatinga: influence of ecological and historical factors. Herpetol. J. 25:109-121.

Pryor GS, 2003. Growth rates and digestive abilities of bullfrog tadpoles (Rana catesbeiana) fed algal diets. J. Herpetol. 37:560-566.

Ranvestel AW, Lips KR, Pringle CM, Whiles MR, Bixby R, 2004. Neotropical tadpoles influence stream benthos: evidence for the ecological consequence of decline in amphibian populations. Freshwater Biol. 49:274-285.

Rodrigues MT, Caramaschi U, Mijares A, 2010. Scinax $x$ signatus. The IUCN Red List of Threatened Species 2010. Available from. dx.doi.org/10.2305/IUCN.UK.20102.RLTS.T56005A11404900.en.

Rodrigues R, Albuquerque RL, Santana DJ, Laranjeiras DO, Protázio AS, França FGR, Mesquita DO, 2013. Record of the occurrence of Lachesis muta (Serpentes, Viperidae) in an Atlantic Forest fragment in Paraíba, Brazil, with comments on the species' preservation status. Biotemas 26:283-286.

Rossa-Feres DC, Jim J, Fonseca MG, 2004. Diets of tadpoles from a temporary pond in southeastern Brazil (Amphibia, Anura). Rev. Bras. Zool. 21:745-754.

Sá RO, Grant T, Camargo A, Heyer WR, Ponssa ML, Stanley E, 2014. Systematics of the neotropical genus Leptodactylus Fitzinger, 1826 (Anura: Leptodactylidae): phylogeny, the relevance of non-molecular evidence, and species accounts. South Am. J. Herpetol. 9:1-128.

Santos EM, Amorim FO, 2005. Modo reprodutivo de Leptodactylus natalensis Lutz, 1930 (Amphibia, Anura, Leptodactylidae). Rev. Bras. Zoociências 7:39-45.

Santos EM, Amorim FO, 2006. Cuidado parental em Leptodactylus natalensis (Amphibian, Anura, Leptodactylidae). Iheringia 96:491-494.

Santos FJM, Protázio AS, Moura CWN, Juncá FA, 2016. Diet and food resource partition among benthic tadpoles of three anuran species in Atlantic Forest tropical streams. J. Freshwater Ecol. 31:53-60.

Seale DB, 1980. Influence of amphibian larvae on primary production, nutrient flux, and competition in a pond ecosystem. Ecology 61:1531-1550.

Sousa Filho IF, Branco CC, Carvalho-e-Silva AMPT, Silva GR, Sabagh LT, 2007. The diet of Scinax angrensis (Lutz) tadpoles in an area of the Atlantic Forest (Mangaratiba, Rio de Janeiro) (Amphibia, Anura, Hylidae). Rev. Bras. Zool. 24:965-970.

Steinwascher K, Travis J, 1983. Influence of food quality and quantity on early larval growth of two anurans. Copeia 1:238-242.

Wells KD, 2007. The ecology and behavior of amphibians. University of Chicago Press, Chicago. 